\title{
Surgical downsizing of a prosthetic ring in congenital mitral valve regurgitation
}

\author{
Rita Ataíde Silva (ㄷ, ' Susana Cordeiro, ${ }^{1}$ Isabel Menezes, ${ }^{1}$ Jose Neves ${ }^{2}$
}

'Paediatric Cardiology, Centro Hospitalar de Lisboa Ocidental EPE, Lisbon, Portugal ${ }^{2}$ Cardiac Surgery, Centro Hospitalar de Lisboa Ocidental EPE, Lisbon, Portugal

\section{Correspondence to Dr Rita Ataíde Silva; ritataide@gmail.com}

Accepted 21 May 2020

\section{DESCRIPTION}

Isolated congenital mitral valve regurgitation is an extremely rare disease in children in the first year of life. ${ }^{1}$ It can progress quickly to severe regurgitation, leading to left ventricular enlargement and remodelling, with decline in ejection fraction. ${ }^{2}$ In such cases, the dilated annulus and leaflet abnormities are complex and difficult to manage. Because it is usually complex, intervention is ideally postponed allowing time for annular growth and tissue maturity. ${ }^{3}$

We present a case of a 2-month-old girl with a history of poor feeding, respiratory distress, pallor and poor weight gain. The baby was evaluated by paediatric cardiology due to a heart murmur grade IV/VI on Levine scale. Transthoracic echocardiography showed an arcade mitral valve (Hammock) with major valvar regurgitation, dysplastic leaflets, with incomplete coaptation, an extremely dilated valvar ring (z-score +9.54$)^{4}$ (video 1 ) and massive dilation of the left atrium. There were no other valve or coronary artery abnormalities. Even though there was some improvement with anticongestive medication, she remained on cardiac failure and was proposed for surgical intervention at 6 months of age. Informed consent was obtained from parents prior to the intervention, concerning the need for an intraoperative modifying device.

Surgical findings: huge circular mitral annulus $(26 \mathrm{~mm})$, a large anterior leaflet, thick and yellowish pliable tissue, anomalous subvalvular apparatus with a large anterior papillary muscle attached to a small posterior papillary muscle and short chordae. The surgical intervention consisted of longitudinal division of both papillary muscles, resulting in three separate heads and mitral annuloplasty. Because we were aiming for anteroposterior reduction without too big an annulus size reduction, we chose a rigid Carpentier Edwards Physio Ring. As the smallest available size was too large for this patient, the posterior part of the ring was cut out over a length of $12 \mathrm{~mm}$. The annulus was bent, the two ends were

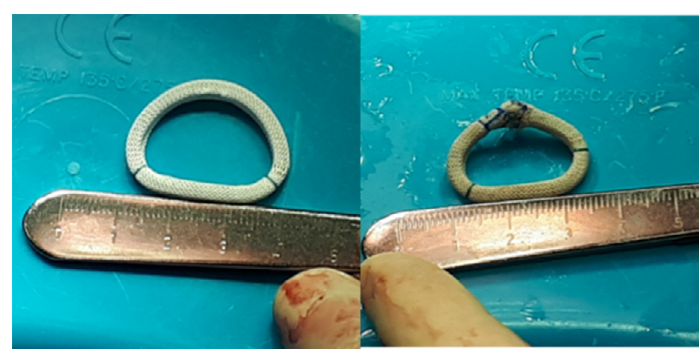

Figure 1 Carpentier Edwards Physio Ring transformation during surgery.

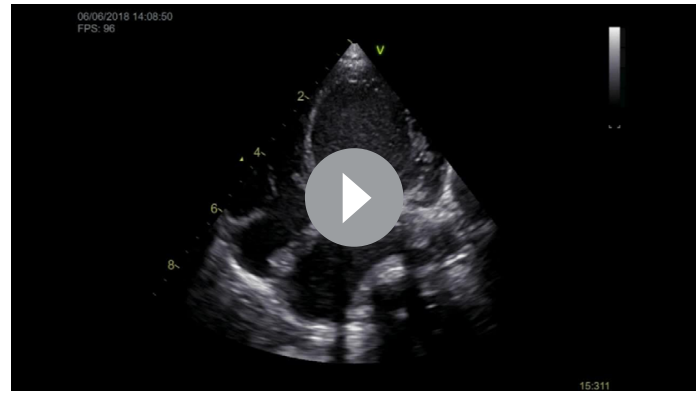

Video 1 Transthoracic echocardiogram before and after surgery, from an apical four-chamber view with and without colour Doppler.

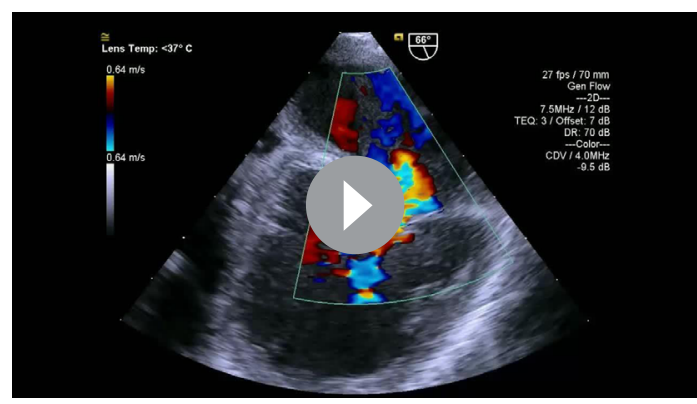

Video 2 Transoesophageal echocardiogram before and after surgery, with mitral valve with and without colour Doppler.

joined together and covered by its own Dacron tissue. The final diameter was approximately $20 \mathrm{~mm}$ maintaining the original shape (figure 1). Transthoracic echocardiogram after surgery showed a vast reduction of mitral regurgitation and better leaflet coaptation (video 2).

Two years after the surgery, the child has reached the 75 th centile of weight, progressively with lower symptoms of cardiac insufficiency, maintaining captopril therapy for minor mitral regurgitation

\section{Patient's perspective}

As parents, we were extremely concerned about our baby's failure to thrive during the first months of life. As soon as she initiated medication, she improved but we were hopeful on surgery results. The fear of losing her was always present but steeped after the surgery, as she started to gain weight and feel much better. We are very grateful to all the medical teams that did the best for our little child. 


\section{Learning points}

- Anticongestive medication should be optimised but can be insufficient to support adequate thrive until the ideal intervention time.

- Although there are no consensual surgical treatments for congenital mitral regurgitation, all efforts should be made to preserve the native valve.

- Modifications of prosthetic material can be safe and life-saving.

with no stenosis (median mitral gradient $4.9 \mathrm{~mm} \mathrm{Hg}$ ) and systolic pulmonary artery pressure of $40 \mathrm{~mm} \mathrm{Hg}$.

Mitral regurgitation is extremely rare among congenital heart diseases. For that reason, surgical management may not be consensual or strictly established. Native valve preservation ought to be always aimed for. This case clearly exemplifies how medical treatment was insufficient and surgical treatment was effective. Each rare case must be evaluated by a multidisciplinary experienced team to best portray its treatment.
Contributors RAS and SC have collected all data (images, medical records, etc), took care before and after surgery, during ICU internment. IM made the diagnose and is her main doctor. JN was the main surgeon who operated the baby.

Funding The authors have not declared a specific grant for this research from any funding agency in the public, commercial or not-for-profit sectors.

Competing interests None declared.

Patient consent for publication Parental/guardian consent obtained.

Provenance and peer review Not commissioned; externally peer reviewed.

ORCID iD

Rita Ataíde Silva http://orcid.org/0000-0002-2090-0984

\section{REFERENCES}

1 Lai W. Echocardiography in pediatric and congenital heart disease: from fetus to adult. Blackwell Publishing, 2009.

2 Séquéla P-E, Houyel L, Acar P, et al. Congenital malformations of the mitral valve. Arch Cardiovasc Dis 2011;104:465-79.

3 Oppido G, Davies B, McMullan DM, et al. Surgical treatment of congenital mitral valve disease: midterm results of a repair-oriented policy. J Thorac Cardiovasc Surg 2008;135:1313-21.

4 Sluysmans T, Colan SD, Cohen MS, et al. Structural measurements and adjustment for growth. In: Lai WW, Cohen MS, Geva T, et al, eds. Echocardiography in pediatric and congenital heart disease, 2009.

Copyright 2020 BMJ Publishing Group. All rights reserved. For permission to reuse any of this content visit

https://www.bmj.com/company/products-services/rights-and-licensing/permissions/

BMJ Case Report Fellows may re-use this article for personal use and teaching without any further permission.

Become a Fellow of BMJ Case Reports today and you can:

- Submit as many cases as you like

- Enjoy fast sympathetic peer review and rapid publication of accepted articles

- Access all the published articles

Re-use any of the published material for personal use and teaching without further permission

Customer Service

If you have any further queries about your subscription, please contact our customer services team on +44 (0) 2071111105 or via email at support@bmj.com.

Visit casereports.bmj.com for more articles like this and to become a Fellow 